DOI: $10.19195 / 0137-1134.106 .22$

\author{
JOANNA FILABER
}

Wyższa Szkoła Prawa im. H. Chodkowskiej we Wrocławiu

\title{
UBEZPIECZENIA INDYWIDUALNE MINIMALIZUJĄCE SKUTKI WYSTĘPOWANIA ZAGROŻEŃ
}

\section{WPROWADZENIE}

W systemie bezpieczeństwa wewnętrznego Rzeczypospolitej Polskiej istotną rolę powinny odgrywać obowiązkowe indywidualne ubezpieczenia majątkowe, których celem byłoby zarówno zabezpieczenie, jak i ochrona przed ryzykiem wystąpienia katastrof naturalnych. Czynnikiem charakteryzującym ubezpieczenia indywidualne w zakresie zagrożeń spowodowanych siłami natury powinna być obligatoryjność dla każdego mieszkańca gminy, i to niezależnie od potencjalnego poziomu zagrożeń występujących na terenie podstawowej jednostki samorządu terytorialnego.

Ochrona bezpieczeństwa mieszkańców demokratycznego państwa prawnego jako podstawowe i najważniejsze zadanie publiczne Rzeczypospolitej Polskiej obejmuje: bezpieczeństwo wewnętrzne, bezpieczeństwo zewnętrzne i bezpieczeństwo socjalne. Zapewnienie przedmiotowej ochrony w państwie jest złożonym zadaniem publicznym zarówno dla organów administracji publicznej (poziom centralny, samorządowy - w tym gminny ${ }^{1}$ ), jak i służb i formacji mundurowych.

Realizacja zadań publicznych w zakresie bezpieczeństwa wewnętrznego wiąże się z koniecznością zapobiegania różnym zagrożeniom powodującym szkody dla państwa i samych obywateli. Tymczasem mieszkańcy każdej gminy w Polsce mogliby minimalizować lub całkowicie chronić się przed skutkami i następstwami zagrożeń spowodowanych siłami natury (powódź, burze, huragany, tornada, trzęsienia ziemi, pożary, opady śniegu, gradobicie itp.), zawierając obowiązkową umowę ubezpieczeniową.

1 Więcej na temat ochrony bezpieczeństwa publicznego na terenie podstawowej jednostki samorządu terytorialnego w kontekście obligatoryjności zadań publicznych wójtów (burmistrzów, prezydentów miast) oraz organu stanowiącego gminy, podejmowanych do ochrony bezpieczeństwa indywidualnego każdego mieszkańca gminy w czasie sytuacji kryzysowej i podczas stanów nadzwyczajnych zob. J. Filaber, Ochrona bezpieczeństwa publicznego w gminie, Warszawa 2016. 
Obecny stan prawny systemu ubezpieczeń od skutków zagrożeń naturalnych — szczególnie w odniesieniu do zagrożenia powodzi w Polsce - to ustawowy dychotomiczny podział ubezpieczeń od skutków powodzi na dobrowolne ubezpieczenia od skutków powodzi i obowiązkowe ubezpieczenia od skutków powodzi. W obecnym stanie prawnym powszechny obowiązek ubezpieczeń od ryzyka żywiołów w Rzeczypospolitej Polskiej dotyczy wyłącznie polskiego rolnictwa ${ }^{2}$, a szczegółowo - systemu ubezpieczeń upraw rolnych i zwierząt gospodarskich ${ }^{3}$ oraz ubezpieczenia budynków rolniczych. Pozostała grupa ubezpieczonych objęta jest systemem fakultatywnego ubezpieczenia od zdarzeń żywiołowych, a ich prawa i obowiązki kształtowane są jedynie na podstawie ogólnych warunków ubezpieczenia wyznaczanych przez ubezpieczyciela.

Istniejący system wykazuje niedoskonałości i nie gwarantuje odpowiedniego poziomu bezpieczeństwa jednostki, której ubezpieczyciel może na przykład odmówić zawarcia umowy ubezpieczeniowej ze względu na położenie należącej do niej nieruchomości na terenach o podwyższonym ryzyku powodziowym. Nadto, system nie powoduje wzrastającej świadomości obywateli w zakresie konieczności wła-

2 Zob. I. Lipińska, Z problematyki ubezpieczeń upraw rolnych $i$ zwierzą gospodarskich, „Przegląd Prawa Rolnego” 2012, nr 2.

3 Powszechny obowiązek ubezpieczeń upraw i zwierząt gospodarskich istniał w RP do $1990 \mathrm{r}$. Ustawowe ubezpieczenie upraw obejmowało ryzyko gradobicia, powodzi, ognia oraz wskutek zalania, nadmiernych opadów i dotyczyło zbóż, roślin pastewnych przeznaczonych na paszę, ziemniaków, buraków cukrowych oraz łąk i pastwisk. Obowiązek ubezpieczenia dotyczył także zwierząt; zob. więcej C. Klimowski, Perspektywy rynku ubezpieczeń produkcji rolnej w Polsce i Unii Europejskiej, Warszawa 2002. Na zasadach wolnorynkowych ubezpieczenia rolne pojawiły się z dniem wejścia ustawy z dnia 28 lipca 1990 r. o działalności ubezpieczeniowej. Zniesienie obowiązku ubezpieczenia upraw i zwierząt spowodowały, że od lat 90. aż do roku 2008 r. ubezpieczonych było tylko kilka procent areału upraw i kilka procent zwierząt. Ochrona ubezpieczeniowa rolnictwa była niewystarczająca, co potwierdziły zdarzenia, między innymi powódź w 1997 r. i susza w 2006 r., które wykazały słabość i niewydolność systemów pomocy państwa, a co najważniejsze — niewielki stopień ubezpieczenia w sektorze rolnym; zob. więcej C. Klimowski, Istota, skutki i zarzadzanie ryzykiem katastroficznym w rolnictwie polskim, Warszawa 2002. W wyniku wspomnianych zdarzeń zaistniała konieczność wprowadzenia rozwiązań systemowych, polegających na dotowaniu składki na ubezpieczenie upraw rolnych i zwierząt gospodarskich przez państwo. Skutkiem tych działań była ustawa z dnia 7 lipca 2005 r. o dopłatach do ubezpieczeń upraw rolnych i zwierząt gospodarskich (Dz.U. Nr 150, poz. 1249 z późn. zm.), która została nowelizowana w 2007 r. na podstawie ustawy z dnia 7 marca 2007 r. o zmianie ustawy o dopłatach do ubezpieczeń upraw rolnych i zwierząt gospodarskich oraz niektórych innych ustaw (Dz.U. Nr 49, poz. 328). Ustawa z dnia 7 marca 2007 r. miała zachęcić rolników i firmy ubezpieczeniowe do zawierania umów chroniących przed skutkami wystąpienia klęsk żywiołowych. Dnia 8 sierpnia 2008 r. weszła w życie kolejna nowelizacja ustawy z dnia 7 lipca 2005 r., która usprawniła system ubezpieczeń w rolnictwie. Należy zauważyć, że wprowadzenie obowiązku ubezpieczenia upraw rolnych jest konieczne w związku z unijnym obowiązkiem posiadania polis ubezpieczenia 50\% upraw rolnych przez rolników, którzy ubiegają się o inne formy wsparcia $\mathrm{z}$ budżetu krajowego w przypadku wystąpienia klęsk żywiołowych, cyt. za: M. Józefecka, U. Tetwejer, Ubezpieczenia od ryzyka wystapienia klęsk żywiołowych w polskim rolnictwie na tle ustawodawstwa unijnego, „Ubezpieczenia w Rolnictwie. Materiały i Studia” 2009, nr 1, s. 174. 
ściwego zabezpieczenia swoich nieruchomości przed nieprzewidzianymi skutkami zagrożeń powodziowych oraz właściwego zarządzania ryzykiem w obliczu nasilających się zmian klimatycznych oraz zmniejszającej się roli ochronnej państwa.

Artykuł ma dwa cele główne. Pierwszym jest przedstawienie obecnego systemu prawnego ubezpieczeń od katastrof naturalnych — szczególnie w odniesieniu do zagrożenia powodzi. Kolejnym jest próba odpowiedzi autorki na pytanie, czy zmiany sformułowane w artykule jako wnioski de lege ferenda w kontekście ustawowej obligatoryjności natychmiastowego przeobrażenia — niezwłocznej ewolucji i wprowadzenia systemu powszechnych ubezpieczeń od katastrof naturalnych będzie w stanie zrekompensować ubezpieczonym - każdemu obywatelowi RP — i ubezpieczycielom przeniesioną na nich odpowiedzialność za zarządzanie ryzykiem katastrof naturalnych, które w obecnym stanie prawnym jest niwelowane systemem dobrowolnych ubezpieczeń od powodzi, oraz czy rozwiąże problem niewystarczającej pomocy państwa na wypadek przyszłej sytuacji kryzysowej w obszarze katastrof naturalnych.

\section{ZAGROŻENIA BEZPIECZEŃSTWA WEWNĘTRZNEGO W RZECZYPOSPOLITEJ POLSKIEJ}

Ze względu na zwiększającą się możliwość zagrożeń bezpieczeństwa wewnętrznego i zachodzącej tym samym zmianie poziomu akceptowalnego zagrożenia bezpieczeństwa indywidualnego współczesne państwa, dokonując taksonomii zagrożeń, wyznaczają zadania publiczne właściwym podmiotom oraz regulują prawne formy działania organów administracji publicznej, służb i formacji mundurowych, organizacji społecznych, a także samych ubezpieczycieli.

Analiza poglądów przedstawicieli nauki prawa administracyjnego ${ }^{4}$ i nauki o bezpieczeństwie ${ }^{5}$ prowadzi do konstatacji, że $\mathrm{w}$ demokratycznym państwie większość przedstawicieli doktryny dokonała klasyfikacji zagrożeń w odniesieniu do stanów nadzwyczajnych i sytuacji kryzysowych na:

1) zagrożenia spowodowane siłami natury (powódź, burze, huragany, tornada, trzęsienia ziemi i pożary, zagrożenia związane z opadami śniegu);

2) zagrożenia spowodowane awariami technicznymi (zagrożenia spowodowane katastrofami budowlanymi, katastrofą komunikacyjną, awarią chemiczną, wypadkiem radiacyjnym);

3) zagrożenia spowodowane działaniami terrorystycznymi.

Ze względu na wysoki poziom ryzyka wystąpienia zagrożeń katastrofami naturalnymi, a w szczególności zagrożeń powodziowych dalsza część artykułu bę-

${ }^{4}$ Zob. więcej o rodzajach bezpieczeństwa wewnętrznego na podstawie taksonomii zagrożeń S. Pieprzny, Ochrona bezpieczeństwa i porządku publicznego, Rzeszów 2007, s. 18-24.

5 Podziału zagrożeń dokonał między innymi R. Grocki, Vademecum zagrożeń, Warszawa 2012. 
dzie poświęcona tematyce systemu ubezpieczeń jako instrumentu minimalizujące skutki występowania zagrożeń powodziowych będących katastrofami naturalnymi.

\section{OBECNY SYSTEM UBEZPIECZEŃ OD RYZYKA WYSTĄPIENIA KATASTROF NATURALNYCH}

W polskim systemie prawnym problematyka ubezpieczeniowa ${ }^{6}$ regulowana jest w ustawie z dnia 23 kwietnia 1964 r. Kodeks cywilny ${ }^{7}$ — tytuł XXVII „Umowa ubezpieczenia", a także w ustawach szczegółowych (między innymi ustawa z dnia 11 września 2015 r. o działalności ubezpieczeniowej i reasekuracyjnej ${ }^{8}$, ustawa z dnia 22 maja 2003 r. o ubezpieczeniach obowiązkowych, Ubezpieczeniowym Funduszu Gwarancyjnym i Polskim Biurze Ubezpieczycieli Komunikacyjnych $^{9}$, ustawa z dnia 22 maja 2003 r. o nadzorze ubezpieczeniowym i emerytalnym ${ }^{10}$, ustawa z dnia 22 maja 2003 r. o pośrednictwie ubezpieczeniowym ${ }^{11}$ ), jak też w przepisach prawa $\mathrm{UE}^{12}$, w większości inkorporowanych do ustaw krajowych.

Stosownie do brzmienia art. 805 k.c. umową ubezpieczenia ubezpieczyciel zobowiązuje się, w zakresie działalności swego przedsiębiorstwa, spełnić określone świadczenie w razie zajścia przewidzianego w umowie wypadku, a ubezpieczający zobowiązuje się zapłacić składkę. Przy ubezpieczeniu majątkowym świadczenie ubezpieczyciela polega w szczególności na zapłacie określonego odszkodowania za szkodę powstałą wskutek przewidzianego w umowie zdarzenia powodzi, gradobicia, pożaru i innych żywiołów. Przedmiotem ubezpieczenia majątkowego może być każdy interes majątkowy, który nie jest sprzeczny z prawem i daje się ocenić w pieniądzu.

Regulacja prawa cywilnego zawarta w art. 822 k.c. wprost kształtuje zakres odpowiedzialności cywilnej ubezpieczyciela i jest wyartykułowana w założeniu,

${ }^{6} \mathrm{Na}$ temat historii polskiego systemu prawnego ubezpieczeń majątkowych należy polecić przede wszystkim M. Szcześniak, U progu trzeciego stulecia ubezpieczeń-historia ubezpieczeń na ziemiach polskich, Warszawa 1999. Zob. także na temat ubezpieczeń gospodarczych P. Ziółkowski, Ubezpieczenia gospodarcze, „Serwis Prawno-Pracowniczy” 2002, nr 22; oraz R. Garbiet, Ubezpieczenia w teorii i praktyce, Częstochowa 2003.

7 Dz.U. z 2016 r., poz. 380 ze zm.

8 Dz.U. z 2015 r., poz. 1844 ze zm.

9 Dz.U. z 2013 r., poz. 392 ze zm.

10 Dz.U. z 2013 r., poz. 290 ze zm.

11 Dz.U. z 2014 r., poz. 1450 ze zm.

12 Zob. więcej między innymi dyrektywa Rady 92/49/EWG z dnia 18 lipca 1992 r. w sprawie koordynacji przepisów ustawowych, wykonawczych i administracyjnych odnoszących się do ubezpieczeń bezpośrednich innych niż ubezpieczenia na życie oraz zmieniająca dyrektywę 73/239/ EWG (trzecia dyrektywa w sprawie ubezpieczeń innych niż ubezpieczenia na życie, Dz. Urz. WE L nr 228, s. 1). 
iż uprawniony do odszkodowania w związku ze zdarzeniem objętym umową ubezpieczenia majątkowego może dochodzić roszczenia bezpośrednio od ubezpieczyciela. Tym samym ubezpieczyciel nie może przeciwko uprawnionemu do odszkodowania podnieść zarzutu naruszenia obowiązków wynikających z umowy lub ogólnych warunków ubezpieczenia przez ubezpieczonego, jeżeli ono nastąpiło po zajściu wypadku, w tym katastrofy naturalnej. Należy podkreślić, że jeżeli strony umowy ubezpieczenia (ubezpieczyciel i ubezpieczony) nie określiły w ramach zasady swobody kształtowania treści umów inaczej, suma ubezpieczenia ustalona w umowie stanowi górną granicę odpowiedzialności ubezpieczyciela.

Warunki wykonywania działalności w zakresie ubezpieczeń majątkowych określa ustawa z dnia 11 września 2015 r. o działalności ubezpieczeniowej i reasekuracyjnej ${ }^{13}$. Zgodnie z treścią art. 4 ust. 7 pkt 1 przedmiotowej ustawy czynnościami ubezpieczeniowymi związanymi z oferowaniem i udzieleniem przez zakład ubezpieczeń ochrony na wypadek ryzyka wystąpienia skutków katastrof naturalnych jest między innymi zawieranie umów ubezpieczenia, umów gwarancji ubezpieczeniowych lub zlecanie ich zawierania uprawnionym pośrednikom ubezpieczeniowym. Do zadań ubezpieczeniowych regulowanych ustawowo należy też ocena ryzyka powodziowego w ubezpieczeniach majątkowych oraz sama już wypłata odszkodowania i innych należności z tytułu zawartej umowy ubezpieczeniowej. W zakresie czynności ubezpieczeniowych mieści się także ustalanie przyczyn i okoliczności zdarzeń powodujących katastrofy naturalne, ustalanie wysokości szkód oraz rozmiaru odszkodowań.

W demokratycznym państwie prawa dla każdego człowieka najistotniejsze jest zapewnienie ochrony przed zagrożeniami. W przypadku niemożliwości zagwarantowania pełnego bezpieczeństwa i tym samym przy niezapewnieniu pełnej ochrony wobec chociażby takich zagrożeń, jak powódź, będąca zjawiskiem realnym, dla każdego ubezpieczającego istotne będzie nie tylko uzyskanie satysfakcjonujących warunków ochrony ubezpieczeniowej, lecz także sprawny przebieg likwidacji szkody i wypłaty słusznego odszkodowania ${ }^{14}$.

Należy postawić pytanie: czy każdy ubezpieczony w Rzeczypospolitej Polskiej ma ustawowo zagwarantowaną taką samą ochronę i tym samym wobec każdego ubezpieczającego ubezpieczyciel określa granicę odpowiedzialności za powstałą realną szkodę $\mathrm{w}$ wyniku katastrofy naturalnej? Udzielając odpowiedzi, należy odnieść się do dwóch obszarów ubezpieczeniowych, to jest do gwarancji ubezpieczeniowej i do charakteru prawnego ubezpieczeń od katastrof naturalnych.

Odnosząc się do gwarancji ubezpieczeniowej, czyli instrumentu finansowego ustalającego limit odpowiedzialności ubezpieczyciela, należy podkreślić, że gra-

13 Dz.U. z 2015 r., poz. 1844 ze zm.

14 Pogląd ten potwierdza w doktrynie między innymi M. Rudnicki, Ustugi ubezpieczeniowe jako instrument wspomagajacy realizację inwestycji przez jednostki samorządu terytorialnego, [w:] Wspólzależność dyscyplin badawczych w sferze administracji publicznej, red. S. Wrzosek et al., Warszawa 2010, s. 317. 
nicą tej odpowiedzialności jest tylko wysokość poniesionej szkody. Za samo zaś wystawienie gwarancji ubezpieczony płaci składkę. Jej wysokość opiera się na ocenie pojedynczego ryzyka i jest uzależniona od rodzaju gwarancji, wysokości sumy gwarancyjnej, okresu trwania gwarancji i rodzaju zabezpieczenia ${ }^{15}$.

W kontekście drugiego obszaru ubezpieczeniowego należy pamiętać, że w obecnym stanie prawnym ustawodawca nie wprowadził do porządku prawnego zasad obowiązkowego zawierania ubezpieczenia dla każdego mieszkańca Rzeczypospolitej Polskiej. Tym samym ubezpieczenia te zawierane są jedynie na podstawie obowiązujących ogólnych warunków poszczególnych ubezpieczeń oraz na podstawie wynegocjowanych indywidualnych szczególnych klauzul i postanowień umownych ${ }^{16}$. Z tego też względu treść poszczególnych umów w odniesieniu do zakresu ochrony ubezpieczeniowej oraz do innych istotnych postanowień umownych, w indywidualnych przypadkach, może znacznie się różnić, co przekłada się bezpośrednio na poziom granicy ochrony ubezpieczonego.

\section{UBEZPIECZENIA JAKO NARZĘDZIA ZARZĄDZANIA RYZYKIEM}

Rozważanie problemu minimalizowania skutków zagrożeń w zakresie katastrof naturalnych jest niedoskonałe bez analizy możliwych do zastosowania różnorodnych mechanizmów ochrony. Jednakże zastosowanie technicznych ${ }^{17}$ mechanizmów ochrony powinno zawsze być poprzedzone edukacją ${ }^{18} \mathrm{~W}$ aspekcie świadomości ryzyka powodziowego ${ }^{19}$, która tylko w procesie ciągłym pozwala stworzyć realny system ochrony przeciwpowodziowej.

15 M. Szczepańska-Bębenek, Gwarancje w ofercie ubezpieczyciela. Jak zabezpieczyć wykonanie kontraktu?, „Prawo Przedsiębiorcy” 2002, nr 16.

16 M. Rudnicki, op. cit., s. 319-320.

17 Działania techniczne mające na celu zmniejszenie zagrożeń i minimalizację skutków. Odnosząc się do działań technicznych w aspekcie zagrożeń powodziowych, należy wskazać, że działania te mają na celu budowę i eksploatację urządzeń wodnych dla zapewnienia ochrony pojedynczych obiektów lub ich zespołów oraz terenów przed powodzią. Redukcja strat następuje poprzez wpływ na przebieg powodzi tzn. na wielkość kulminacji, czas jej trwania, rozkład przestrzenny przy pomocy urządzeń technicznych, takich jak: zbiorniki retencyjne, suche zbiorniki przeciwpowodziowe, poldery, obwałowania i inne, cyt. za: A. Łasut, Korzyści i koszty z wprowadzenia w Polsce systemu ubezpieczeń obowiązowych od skutków powodzi, Kraków 2006, s. 36.

18 Edukacja należy do działań nietechnicznych. Same zaś działania nietechniczne to działania prawne, organizacyjne, administracyjne, ekonomiczne mające na celu złagodzenie skutków zagrożenia. Odnosząc się do zagrożenia powodziowego, należy wskazać, że do działań nietechnicznych zaliczyć trzeba redukcję strat następującą przez oddziaływanie na organizację życia oraz zachowania mieszkańców i użytkowników terenu potencjalnie zagrożonych powodzią przez regulacje prawne, systemy ubezpieczeń i inne instrumenty finansowe, transfery ryzyka, podatków, edukację i sprawne systemy ostrzeżeń powodziowych, cyt. za: ibidem.

19 Ryzyko powodziowe jest to kombinacja prawdopodobieństwa wystąpienia zjawiska powodzi oraz możliwych negatywnych konsekwencji powodzi dla zdrowia i życia ludzi, gospodarki, 
Odnosząc się do narzędzi zarządzania ryzykiem ${ }^{20}$, podkreślić należy, że w doktrynie początkowo przeważał pogląd odnoszący się jedynie do represyjnych działań, które polegały na tłumieniu negatywnych skutków zdarzenia losowego (na przykład przenoszenie ruchomości z zalanych pomieszczeń do pomieszczeń znajdujących się na wyższych piętrach lub przez wypompowywanie wody z zalanych pomieszczeń). Następnie zaczęto podejmować działania związane z prewencją, która polegała na zapobieganiu negatywnym skutkom zdarzenia losowego (na przykład dbanie o sieć melioracyjną). Ostatecznie ukształtowało się założenie o kompensacji zagrożeń ${ }^{21}$, która polega na wyrównywaniu negatywnych skutków zdarzenia losowego. Przykładem kompensacji są właśnie ubezpieczenia od skutków powodzi, a także od gradobicia, akcji terrorystycznej, zagrożeń chemicznych, radiacyjnych, epidemii, epizootii i innych.

\section{WNIOSKI DE LEGE FERENDA}

Ustawodawca w obecnym stanie prawnym nie wprowadza przymusu zawierania obowiązkowych ubezpieczeń gospodarczych od katastrof naturalnych i innych zagrożeń, wyjątek obejmuje jedynie wąską grupę ubezpieczeń budynków rolniczych. Dodatkowo w Rzeczypospolitej Polskiej brakuje doświadczeń w zakresie narzędzi aktywizujących społeczności lokalne do działań prewencyjnych. Nadto w niewielkim stopniu budżet krajowy jest odciążany przez samofinansowanie ubezpieczeń dobrowolnych od zagrożeń naturalnych i cywilizacyjnych. Wszystkie te przesłanki wprost prowadzą do wniosku, że przyszłe obowiązkowe ubezpieczenia od katastrof naturalnych byłyby ważniejszą metodą ograniczania strat wyrządzanych w wyniku sytuacji kryzysowych i stanów nadzwyczajnych w RP. Jednakże stanie się to możliwe, gdy dojdzie do rozdystrybuowania odpowiedzialności za straty katastrof naturalnych między sektorem publicznym

dziedzictwa kulturowego i środowiska, zgodnie z art. 2 dyrektywy 2000/60/WE Parlamentu Europejskiego i Rady z 23 października 2000 r. ustanawiającej ramy wspólnotowego działania w dziedzinie polityki wodnej.

$20 \mathrm{Na}$ temat pojęcia ryzyka, zarządzania ryzykiem i pojęć pokrewnych zob. więcej T.T. Kaczmarek, Ryzyko a zarządzanie ryzykiem. Ujęcie interdyscyplinarne, Warszawa 2006, s. $51 \mathrm{n}$.

21 W doktrynie podejmowane są odmienne próby klasyfikacji instrumentów ochrony przed ryzykiem powodziowym i w jego ramach wyróżnić należy instrumenty prewencji, represji (tłumienia, redukcji), retencji (zatrzymania) i transfer ryzyka — zob. więcej między innymi M. Wieczorek -Kosmala, Rola i znaczenie ubezpieczeń gospodarczych w systemie ochrony przedsiębiorstwa przed ryzykiem, „Finanse” 2009, nr 1, s. 71. Odmiennie tematykę metod zarządzania ryzykiem przedstawia T. Sangowski, który zalicza do nich: unikanie ryzyka, zatrzymywanie ryzyka — świadome (aktywne) zatrzymywanie ryzyka (samoubezpieczenie jest jego szczególnym rodzajem) oraz nieświadome (pasywne, bierne) zatrzymywanie ryzyka, kontrolowanie ryzyka — zapobieganie stratom oraz redukowanie strat, transferowanie ryzyka, dzielenie (dyspersję, dystrybucję, repartycję) ryzyka, ubezpieczenie, za: T. Sangowski, Ubezpieczenia gospodarcze, Warszawa 2001. 
i prywatnym dzięki właśnie ubezpieczeniom obowiązkowym jako instrumentom umożliwiającym partycypację społeczeństwa w stratach.

Podstawową funkcją ubezpieczeń gospodarczych jest zapewnienie środków finansowych na realizację działań w dwóch obszarach. Po pierwsze, na kompensatę szkód i innych kosztów powstałych w związku z wystąpieniem sytuacji kryzysowej spowodowanej zagrożeniami naturalnymi. Po drugie, na prewencję w zakresie ryzyka powstania szkód indywidualnych na obszarze Rzeczypospolitej Polskiej, czyli szerzej na ochronę przyszłego bezpieczeństwa przez edukację.

Korzystając $\mathrm{z}$ dorobku nauki prawa ${ }^{22}$ pod kątem programów zarządzania powodzią, wskazać należy, że poczynione tam wnioski można odnieść wprost do zagrożeń naturalnych. I tym samym wskazać na dwa warianty ubezpieczeń publicznych. Pierwsze rozwiązanie przyjmuje tezę, że to państwo (podatnicy) ponoszą cały ciężar zapobiegania skutkom katastrof naturalnych i usuwania ich lub utworzony zostanie system ubezpieczeń obowiązkowych jako publiczny program ubezpieczeń, czyli rodzaj podatku rozłożonego na wszystkie gospodarstwa domowe. Drugi wariant koncentruje się na całkowitym wycofaniu państwa z oferowanej pomocy finansowej, a istniejące rynki prywatnych ubezpieczeń, na których stawki składek zależą od poziomu ryzyka, są podstawowym narzędziem ochrony przed zagrożeniami ${ }^{23}$.

Mając na względzie powyższe, konstatacja, iż wprowadzenie systemu powszechnych ubezpieczeń obowiązkowych od skutków katastrof naturalnych w Polsce jest uzasadnione - nie budzi wątpliwości. Jednakże uwarunkowania, w których funkcjonują ubezpieczenia od skutków ryzyka naturalnego, są złożone i można je sklasyfikować na: uwarunkowania prawne, uwarunkowania ekonomiczne, uwarunkowania społeczno-kulturowe i uwarunkowania ekologiczne. Wszystkie te uwarunkowania muszą być objęte zakresem badawczym przedstawicieli odpowiednich nauk i tylko interdyscyplinarna ocena kosztów oraz korzyści z wprowadzenia systemu ubezpieczeń obowiązkowych będzie efektywną rekomendacją dalszych badań systemu powszechnych ubezpieczeń indywidualnych minimalizujących skutki występowania zagrożeń w Rzeczypospolitej Polskiej.

22 Zob. więcej T. Sangowski, System finansowy ubezpieczeń gospodarczych w Polsce, Poznań 1992; oraz idem, Vademecum ubezpieczeń gospodarczych, Warszawa 2001. Dodatkowo polecić należy pracę M. Maciejewskiego, Model kompleksowej ochrony przed powodzią, Kraków 2000; idem, Ryzyko w gospodarce wodnej, Warszawa 2000.

23 A. Łasut, op. cit., s. 113-114. 


\title{
INDIVIDUAL INSURANCES MINIMIZING CONSEQUENCES OF NATURAL HAZARDS
}

\begin{abstract}
Summary
The essential role in the internal security system of the Republic of Poland shall be played by compulsory non-life insurances of economic nature. In particular, said insurances shall cover protection of each citizen against the peril of natural disasters.

The current legal regulations of the insurance system against natural disasters, in particular with regard to the peril of flood in Poland, display imperfections and do not guarantee the adequate level of safety of an individual. Moreover, the system does not raise the citizens' awareness of the need of securing their immovable properties against unpredictable consequences of the flooding peril and need of proper risk management in the face of advancing climate change and the decreasing protective role of a state.

This paper attempts to answer the question, whether introducing a system of general insurances could compensate the insured and the insurers for the liability for natural disasters risk management, which has been transferred upon them, and which is currently mitigated by a system of voluntary insurances against the peril of flood. The paper also deals with the problem of the insufficient state aid in the case of emergency situation.
\end{abstract}

